\title{
By-product of passion fruit seed (Passiflora edulis) in the diet of commercial laying hens
}

\author{
Leonardo Henrique Zanetti, Alice Eiko Murakami, Mayra Diaz-Vargas, Ana Flávia Quiles \\ Garcia Guerra, Ivan Camilo Ospina-Rojas, Paula Toshimi Matumoto Pintro, and \\ Valquíria Cação Cruz-Polycarpo
}

\begin{abstract}
This study evaluated the effects of the inclusion of the by-product passion fruit seed (BPFS) in the diet of laying hens on performance, blood variables, quality, and lipid oxidation in eggs. A total of 384 Hy-line W36 layers (32 wk old) were distributed in a completely randomized design, with six treatments (control, 2.5\%, 5.0\%, 7.5\%, $10.0 \%$, and $12.5 \%$ inclusion of BPFS), eight replicates and eight birds each. The productive performance was evaluated for three cycles of $28 \mathrm{~d}$ each. There was no difference $(P>0.05)$ in egg production and feed conversion. However, feed intake showed increased linearly $(P<0.05)$. The egg weight, egg mass, percentage of eggshell, eggshell thickness, and Haugh unit did not differ $(P>0.05)$; however, the specific gravity of eggs increased $(P<0.05)$. Total cholesterol and blood triglycerides decreased linearly $(P<0.05)$. To evaluate the lipid yolk oxidation, a $6 \times 5 \times 2$ factorial design (six levels of BPFS $\times$ five storage periods $\times$ two temperatures) was used. There was an interaction $(P<0.05)$ among the levels of BPFS, time, and storage temperature with the lowest oxidation level of $12.5 \%$ when eggs were refrigerated. The BPFS can be included at a level up to $5.0 \%$ without compromising bird performance and $12.5 \%$ for egg quality, and this level reduced yolk lipid oxidation.
\end{abstract}

Key words: performance, egg quality, oxidation, by-product of fruit.

Résumé : Cette étude avait pour but d'évaluer les effets de l'incorporation du sous-produit de la graine du fruit de la passion (BPFS - " by-product passion fruit seed ") dans la diète des poules pondeuses sur la performance, les variables sanguins ainsi que la qualité et l'oxydation lipidique des œufs. Un total de 384 poules pondeuses de race Hy-line W36 (âgées de 32 semaines) ont été distribuées de façon complètement aléatoire, avec six traitements (témoin; 2,5 \%, 5,0 \%, 7,5 \%, 10,0 \% et 12,5 \% d'inclusion de BPFS), huit réplicats de huit poules chaque. La performance productive a été mesurée pendant trois cycles de 28 jours chacun. Il n'y avait aucune différence $(P>0,05)$ dans la production d'œufs et l'indice de consommation. Par contre, l'ingestion d'aliments augmentait de façon linéaire. $(P<0,05)$. Le poids, la masse, le pourcentage de coquille, l'épaisseur de la coquille et l'unité Haugh des œufs ne différaient pas $(P>0,05)$, par contre, la densité des œufs a augmenté $(P<0,05)$. Le cholestérol total et les triglycérides sanguins ont diminué de façon linéaire $(P<0,05)$. Pour évaluer l'oxydation des lipides du jaune d'œuf, un plan expérimental factoriel $6 \times 5 \times 2$ (six niveaux de BPFS $\times$ cinq périodes d'entreposage $\times$ deux températures) a été effectué. Il y avait une interaction $(P<0,05)$ entre les niveaux de BPFS, le temps et la température d'entreposage avec le niveau le plus faible d'oxydation de 12,5\% lorsque les œufs ont été réfrigérés. Les BPFS peuvent être inclus jusqu'à 5,0 \% sans compromettre la performance de la poule et $12,5 \%$ pour la qualité de l'œuf. Ce niveau a également réduit l’oxydation des lipides du jaune d'œuf. [Traduit par la Rédaction]

Mots-clés : performance, qualité des œufs, oxydation, sous-produit de fruit.

Received 11 February 2016. Accepted 20 April 2016.

L.H. Zanetti, A.E. Murakami, M. Diaz-Vargas, A. Flávia Quiles Garcia Guerra, and I.C. Ospina-Rojas. Departamento de Zootecnia, Universidade Estadual de Maringá (UEM), Maringá, PR 87020-900, Brazil.

P.T. Matumoto Pintro. Departamento de Agronomia, Universidade Estadual de Maringá (UEM), Maringá, PR 87020-900, Brazil.

V.C. Cruz-Polycarpo. Universidade Estadual Paulista (UNESP) - Campus de Dracena, Dracena, SP 17900-000, Brazil.

Corresponding author: Leonardo Henrique Zanetti (email: leohzanetti@yahoo.com.br).

Abbreviations: BPFS, by-product passion fruit seed; TBARS, thiobarbituric acid reactive substances.

Copyright remains with the author(s) or their institution(s). Permission for reuse (free in most cases) can be obtained from RightsLink. 


\section{Introduction}

Processing fruit into natural juices and concentrates generates by-products composed of peels and seeds, which are often discarded; these could be used in the production of animal feed or fertilizers, providing a beneficial purpose to humans and the environment (Kobori and Jorge 2005). Passion fruit (Passiflora edulis) is a tropical fruit with production concentrated primarily in South America, with Brazil, Colombia, Peru, and Ecuador as the largest exporters. Brazil is the main producer and consumer of this fruit (IBGE 2013).

The main uses of passion fruit produced in Brazil are as in natura (fresh fruit), as a mining industry pulp, and in juice manufacturing (Claro and Monteiro 2010). Also, the fruit is highly appreciated for its sensory characteristics (Macoris et al. 2011). The juice is a rich source of vitamins $C, A$, and B complex, and one of the richest sources of niacin (vitamin $B_{3}$ ) as well as mineral salts such as calcium, phosphorus, and iron (Franco 1996).

Passion fruit residue obtained from the pulp and seeds can be used as an alternative food ingredient due to its antioxidant and antibacterial activities (López-Vargas et al. 2013). Studies have indicated the presence of flavonoids and polyphenols in the pulp of P. edulis, where in the total flavonoid content was significant compared to other juices that are sources of flavonoids (Zeraik et al. 2010). Research using passion fruit seed in animal feed has shown that it can be fed to broilers, and is thus viable as an alternative food without affecting productive performance (Togashi et al. 2008). The flour of the passion fruit peel is rich in a soluble fiber (pectin) was able to reduce cholesterol levels of the human blood (Ramos et al. 2007).

Passion fruit seeds can be regarded as a good source of essential fatty acids such as linoleic acid (omega-6: $55 \%-66 \%$ ), oleic acid (omega-9; $18 \%-20 \%$ ), palmitic acid (10\%-14\%), and linolenic acid (omega-3, $0.80 \%-1 \%)$, the latter being found in lesser amounts (Leonel et al. 2000). Omega-3 and six fatty acids play important roles in the body, such as the maintenance of cell membranes and the transmission of nerve impulses (Martin et al. 2006). The aim of this study was to evaluate the inclusion of a by-product of passion fruit seed in the diet of laying hens on performance, egg quality, egg lipid oxidation, and blood variables.

\section{Materials and Methods}

The experiment was conducted in the aviary of the Poultry Sector of the Experimental Farm of Iguatemi (FEI), State University of Maringá (UEM), with the approval of the Ethics Committee on Animal Use (CEUA/UEM) (registration no. 35/2014). A total of 384 Hy-line W36 layers, $32 \mathrm{wk}$ old and in their first production cycle, were housed in galvanized wire cages $(100 \mathrm{~cm} \times 40 \mathrm{~cm} \times$ $45 \mathrm{~cm}$ ) at a density of $500 \mathrm{~cm}^{2}$ bird $^{-1}$ in conventional shed with tile clay. The experimental design was completely randomized, with six treatments - control, 2.5\%, 5.0\%, $7.5 \%, 10.0 \%$, and $12.5 \%$ inclusion of by-product passion fruit seed (BPFS) - with eight replicates per treatment and eight birds per experimental unit.

The chemical composition of the passion fruit seed by-product was evaluated according to the methodology of Silva and Queiroz (2006), which showed values of 10.68\% CP (crude protein), 50.22\% NDF (neutral detergent fiber), $43.71 \% \mathrm{ADF}$ (acid detergent fiber), $18.34 \%$ pectin, $3945 \mathrm{kcal} \mathrm{kg}^{-1}$ AMEn (nitrogen-corrected apparent metabolizable energy). The BPFS used presents $4.01 \mathrm{mg}$ $\mathrm{GAE}^{-1}$ (gallic acid equivalent) of phenolic compounds, according to the methodology of Singleton and Rossi (1965).

The by-product of passion fruit, P. edulis (a yellow or sour passion fruit variety), was obtained from extraction of the pulp and peel of passion fruit, and was stored in a cold room $\left(-18{ }^{\circ} \mathrm{C}\right)$. The by-product initially had $60 \%$ humidity and was therefore subjected to dehydration to achieve the humidity between $8 \%$ and $13 \%$. Dehydration of the material was carried out in the sun, with grinding of the material using a mill-type knife $(2.5 \mathrm{~mm}$ in diameter).

The adopted lighting program was $17 \mathrm{~h}$ light $\mathrm{d}^{-1}$ (natural + artificial). The birds were subjected to an adaptation period of $14 \mathrm{~d}$ and evaluated for three periods (cycles) of $28 \mathrm{~d}$ each. Water and food were provided ad libitum. The experimental diets (Table 1) were isoproteic and isocaloric, based on corn and soybean meal and formulated to meet the nutritional requirements of birds in the laying phase (Hy-Line International 2009-2011). Feed intake and feed conversion were evaluated by weighing the rations at the beginning and end of each cycle. In cases of death of the birds, the feed was weighed for the correction of feed intake. Eggs were collected daily to assess egg production.

To analyze the quality of the eggs, the following parameters were assessed at the end of each cycle on four consecutive days: egg weight, egg mass, specific gravity, Haugh unit, percentage, and eggshell thickness (mm). The eggs from each repetition were identified and individually weighed on a precision scale $(0.001 \mathrm{~g})$. Subsequently, eggs underwent specific gravity testing by immersion of the eggs in saline with different densities $\left(1.070,1.074,1.078,1.082\right.$, and $\left.1.086 \mathrm{~g} \mathrm{~mL}^{-1}\right)$, prepared with the assistance of a petroleum hydrometer, by dipping the eggs from the lowest to the highest density.

To determine the Haugh unit, three eggs were analyzed from each repetition. The eggs were broken on a flat glass surface, and the albumen height was obtained from $5 \mathrm{~mm}$ of yolk with the assistance of a digital caliper. The Haugh unit (Haugh 1937) was obtained by the formula: $\mathrm{HU}=100 \times \log \left(H+7.57-1.7 W^{0.37}\right)$, where $H$ refers to the albumen height $(\mathrm{mm})$ and $W$ represents the egg weight $(\mathrm{g})$.

The eggshells were washed and dried at room temperature for $48 \mathrm{~h}$ and then weighed on a precision scale 
Table 1. Ingredients and nutritional composition of the experimental diets.

\begin{tabular}{|c|c|c|c|c|c|c|}
\hline & \multicolumn{6}{|c|}{ Levels by-product of passion fruit seed inclusion (\%) } \\
\hline & Control & 2.5 & 5.0 & 70.5 & 10.0 & 12.5 \\
\hline \multicolumn{7}{|l|}{ Ingredients (\%) } \\
\hline Maize & 60.99 & 59.11 & 57.24 & 55.36 & 53.48 & 51.60 \\
\hline Soybean meal 45\% & 24.48 & 24.16 & 23.83 & 23.51 & 23.19 & 22.87 \\
\hline By-product of passion fruit seed & 0.00 & 2.50 & 5.00 & 7.50 & 10.00 & 12.5 \\
\hline Soybean oil & 3.07 & 2.74 & 2.41 & 2.07 & 1.74 & 1.41 \\
\hline Dicalcium phosphate & 1.06 & 1.05 & 1.04 & 1.04 & 1.03 & 1.02 \\
\hline Limestone & 9.22 & 9.23 & 9.23 & 9.23 & 9.24 & 9.24 \\
\hline Salt & 0.300 & 0.300 & 0.300 & 0.300 & 0.300 & 0.300 \\
\hline Sodium bicarbonate & 0.273 & 0.275 & 0.277 & 0.278 & 0.280 & 0.282 \\
\hline DL-Methionine 99\% & 0.262 & 0.271 & 0.280 & 0.290 & 0.299 & 0.308 \\
\hline L-Lysine $\mathrm{HCl}$ 78.5\% & 0.041 & 0.057 & 0.072 & 0.087 & 0.103 & 0.118 \\
\hline L-Threonine 98\% & 0.043 & 0.053 & 0.064 & 0.074 & 0.084 & 0.095 \\
\hline Vitamin and mineral supplements ${ }^{a}$ & 0.250 & 0.250 & 0.250 & 0.250 & 0.250 & 0.250 \\
\hline BHT $^{b}$ & 0.010 & 0.010 & 0.010 & 0.010 & 0.010 & 0.010 \\
\hline Total & 100.0 & 100.0 & 100.0 & 100.0 & 100.0 & 100.0 \\
\hline \multicolumn{7}{|l|}{ Calculated nutritional composition ${ }^{c}$} \\
\hline Crude protein (\%) & 16.10 & 16.10 & 16.10 & 16.10 & 16.10 & 16.10 \\
\hline Metabolizable energy $\left(\mathrm{kcal} \mathrm{kg}^{-1}\right)$ & 2900 & 2900 & 2900 & 2900 & 2900 & 2900 \\
\hline Digestible lysine (\%) & 0.777 & 0.777 & 0.777 & 0.777 & 0.777 & 0.777 \\
\hline Digestible Met + Cys (\%) & 0.762 & 0.762 & 0.762 & 0.762 & 0.762 & 0.762 \\
\hline Digestible threonine (\%) & 0.591 & 0.591 & 0.591 & 0.591 & 0.591 & 0.591 \\
\hline Available phosphorus (\%) & 0.291 & 0.291 & 0.291 & 0.291 & 0.291 & 0.291 \\
\hline Sodium (\%) & 0.21 & 0.21 & 0.21 & 0.21 & 0.21 & 0.21 \\
\hline Calcium (\%) & 3.90 & 3.90 & 3.90 & 3.90 & 3.90 & 3.90 \\
\hline Chlorine (\%) & 0.22 & 0.22 & 0.22 & 0.22 & 0.22 & 0.22 \\
\hline Crude fiber & 2.35 & 2.96 & 3.57 & 4.18 & 4.79 & 5.40 \\
\hline Electrolyte balance $\left(\mathrm{mEq} \mathrm{kg}{ }^{-1}\right)$ & 186 & 185 & 182 & 180 & 177 & 175 \\
\hline
\end{tabular}

${ }^{a}$ Vitamin and mineral supplements (content kg ${ }^{-1}$ ration): vitamin A: $20000.00 \mathrm{UI}$; vitamin $\mathrm{D}_{3}: 5500.00 \mathrm{UI}$; vitamin E: $15.50 \mathrm{mg}$; vitamin $\mathrm{K}_{3}: 5.00 \mathrm{mg}$; vitamin $\mathrm{B}_{1}: 5.00 \mathrm{mg}$; vitamin $\mathrm{B}_{2}: 7.50 \mathrm{mg}$; vitamin $\mathrm{B}_{6}: 15.00 \mathrm{mg}$; vitamin $\mathrm{B}_{12}: 25.00 \mathrm{mcg}$; Pantotenato de cálcio $15.00 \mathrm{mg}$; Niacina $62.50 \mathrm{mg}$; Ác. fólico $1.00 \mathrm{mg}$; Se $0.25 \mathrm{mg}$; Mn 162.50 mg; Fe 100.00 mg; Cu 25.00 mg; Zn 125.00 mg; I 2.50 mg.

${ }^{b}$ BHT, antioxidant butylhydroxytoluene.

${ }^{c}$ Calculated based on Rostagno et al. (2011).

(0.001 g). After weighing, the eggshell thickness was measured with the assistance of a digital micrometer at four points in the central region of the eggshell.

During the second cycle (38 wk old), the eggs were collected, identified, and packaged in cardboard trays and were stored under refrigerated (mean of $4^{\circ} \mathrm{C}$ ) and nonrefrigerated (mean $22^{\circ} \mathrm{C}$ ) conditions with a $6 \times 5 \times 2$ factorial design (six levels of inclusion of BPFS, five storage periods, and two temperatures). Lipid oxidation was carried out by means of thiobarbituric acid reactive substances (TBARS) analysis after $0,7,14,21$, and $28 \mathrm{~d}$ storage, with three replicates per treatment, using the methodology described by Jung et al. (2012). For these calculations, a standard curve of malondialdehyde was used; the data are expressed as mg malondialdehyde (MDA) $\mathrm{kg}^{-1}$ yolk.

At the end of the last cycle (44 wk old), one bird was selected per replicates and $2.0 \mathrm{~mL}$ of blood was collected via the jugular vein to obtain serum. The determination of total cholesterol $\left(\mathrm{mg} \mathrm{dL}^{-1}\right)$ and blood triglycerides
( $\mathrm{mg} \mathrm{dL}^{-1}$ ) was performed using an enzymatic colorimetric method (Gold Analisa Diagnóstica Ltda) with a BIOPLUS 2000 spectrophotometer (Bioplus Ltda).

The results for each parameter were subjected to analysis of variance (ANOVA) and polynomial regression, using SAEG (2007). To compare the results, the data were subjected to the Dunnett's test at 5\% probability, to compare each of treatments with control.

\section{Results and Discussion}

There was no difference $(P>0.05)$ in egg production or feed conversion $\left(\mathrm{kg} \mathrm{kg}^{-1}\right.$ and $\left.\mathrm{dz} \mathrm{kg}^{-1}\right)$ between the treatments; however, feed intake showed linearly increased $(P<0.05)$ with the increasing by-product levels in the diet (Table 2). By comparing each treatment with the control by the Dunnett's test, the levels of $10.0 \%$ and $12.5 \%$ inclusion of BPFS resulted $(P<0.05)$ in birds with higher feed intake and worse feed conversion than birds fed the control diet. The increased feed intake can be attributed to 
Table 2. Performance, egg quality, and serum variables ( \pm SEM) of laying hens fed diets with levels of inclusion of BPFS.

\begin{tabular}{|c|c|c|c|c|c|c|c|c|}
\hline \multirow[b]{2}{*}{ Item } & \multicolumn{6}{|c|}{ Levels by-product of passion fruit seed inclusion (\%) } & \multirow[b]{2}{*}{ CV (\%) } & \multirow[b]{2}{*}{$P$-value } \\
\hline & Control & 2.5 & 5.0 & 7.5 & 10.0 & 12.5 & & \\
\hline \multicolumn{9}{|l|}{ Performance } \\
\hline Feed intake $\left(\mathrm{g} \mathrm{hen}^{-1} \mathrm{~d}^{-1}\right)$ & $100.80 \pm 1.02$ & $99.92 \pm 1.58$ & $100.47 \pm 1.89$ & $100.18 \pm 2.04$ & $103.63 \pm 0.52^{*}$ & $105.05 \pm 0.46^{*}$ & 3.89 & $0.001^{a}$ \\
\hline Egg production (\%) & $92.85 \pm 0.38$ & $90.18 \pm 1.27$ & $90.16 \pm 2.13$ & $91.46 \pm 1.82$ & $90.83 \pm 1.22$ & $92.37 \pm 1.28$ & 4.51 & NS \\
\hline Feed conversion ratio $\left(\mathrm{kg} \mathrm{kg}^{-1}\right)$ & $1.653 \pm 0.01$ & $1.745 \pm 0.03$ & $1.775 \pm 0.05$ & $1.792 \pm 0.033^{*}$ & $1.794 \pm 0.02^{*}$ & $1.804 \pm 0.01^{*}$ & 5.44 & NS \\
\hline Feed conversion ratio $\left(\mathrm{kg} \mathrm{dz}^{-1}\right)$ & $1.307 \pm 0.01$ & $1.357 \pm 0.02$ & $1.374 \pm 0.02$ & $1.376 \pm 0.02$ & $1.393 \pm 0.01^{*}$ & $1.399 \pm 0.01^{*}$ & 4.01 & NS \\
\hline \multicolumn{9}{|l|}{ Egg quality } \\
\hline Egg weight $(\mathrm{g})$ & $65.41 \pm 0.20$ & $64.83 \pm 0.77$ & $65.71 \pm 0.44$ & $64.74 \pm 0.39$ & $64.63 \pm 0.31$ & $65.12 \pm 0.54$ & 2.08 & NS \\
\hline Egg mass (g) & $61.04 \pm 0.30$ & $58.03 \pm 1.31$ & $59.24 \pm 1.48$ & $59.21 \pm 1.21$ & $58.71 \pm 0.67$ & $60.12 \pm 0.58$ & 4.88 & NS \\
\hline Haugh's units & $98.95 \pm 0.40$ & $99.09 \pm 0.36$ & $99.68 \pm 0.37$ & $98.81 \pm 0.37$ & $98.71 \pm 0.40$ & $99.25 \pm 0.46$ & 1.12 & NS \\
\hline Egg specific gravity $\left(\mathrm{g} \mathrm{mL}^{-1}\right)$ & $1.080 \pm 0.0003$ & $1.080 \pm 0.0003$ & $1.080 \pm 0.0004$ & $1.081 \pm 0.0004$ & $1.081 \pm 0.0004$ & $1.082 \pm 0.0003^{*}$ & 0.09 & $0.001^{b}$ \\
\hline Eggshell (\%) & $8.791 \pm 0.08$ & $8.787 \pm 0.07$ & $8.736 \pm 0.07$ & $8.912 \pm 0.09$ & $8.857 \pm 0.05$ & $8.951 \pm 0.04$ & 2.42 & NS \\
\hline Eggshell thickness (mm) & $0.468 \pm 0.001$ & $0.469 \pm 0.002$ & $0.478 \pm 0.01$ & $0.472 \pm 0.002$ & $0.469 \pm 0.01$ & $0.471 \pm 0.001$ & 2.57 & NS \\
\hline \multicolumn{9}{|l|}{ Serum variables } \\
\hline Total cholesterol ( $\left.\mathrm{mg} \mathrm{dL}^{-1}\right)$ & $113.39 \pm 8.05$ & $112.18 \pm 10.10$ & $101.27 \pm 12.20$ & $89.55 \pm 10.39$ & $85.64 \pm 5.60$ & $83.87 \pm 2.55$ & 22.07 & $0.012^{c}$ \\
\hline Triglycerides $\left(\mathrm{mg} \mathrm{dL}^{-1}\right)$ & $1834.50 \pm 321.66$ & $1774.25 \pm 287.01$ & $1529.25 \pm 355.90$ & $1321.25 \pm 380.26$ & $1314.00 \pm 170.60$ & $1294.75 \pm 127.43$ & 38.29 & $0.017^{d}$ \\
\hline
\end{tabular}

\footnotetext{
Note: *, significant by Dunnett's

${ }^{a} y=97.824+0.5368 x ; R^{2}=0.83$.

$b^{b} y=1.0793+0.0002 x ; R^{2}=0.89$.

$c^{c} y=116.18-2.8903 x ; R^{2}=0.91$.

${ }^{d} y=1799-46.97 x ; R^{2}=0.85$.
} 
Table 3. Malondialdehyde production $\left(\mathrm{mg} \mathrm{kg}^{-1}\right)$ in yolk of laying hens fed diets containing BPFS and stored in refrigerated and nonrefrigerated environment.

\begin{tabular}{|c|c|c|c|c|c|c|}
\hline \multicolumn{7}{|c|}{ Nonrefrigerated (mean $22^{\circ} \mathrm{C}$ ) } \\
\hline \multirow[b]{2}{*}{ Levels of BPFS (\%) } & \multicolumn{5}{|c|}{ Storage periods $(\mathrm{d})$} & \multirow[b]{2}{*}{ P-value } \\
\hline & 0 & 7 & 14 & 21 & 28 & \\
\hline Control & 5.417 & 6.098 & 6.379 & 6.824 & 5.642 & NS \\
\hline 2.5 & 4.495 & 4.673 & 3.521 & 4.392 & 5.780 & NS \\
\hline 5.0 & 5.018 & 5.481 & 3.564 & 3.926 & 6.216 & NS \\
\hline 7.5 & 5.021 & 6.470 & 3.575 & 4.165 & 6.624 & NS \\
\hline 10.0 & 5.127 & 6.334 & 5.708 & 5.163 & 6.071 & NS \\
\hline 12.5 & 5.039 & 5.735 & 5.898 & 5.436 & 4.755 & NS \\
\hline$P$-value & NS & NS & $0.001^{a}$ & $0.001^{b}$ & $0.002^{c}$ & - \\
\hline \multicolumn{7}{|c|}{ Refrigerated (mean $4{ }^{\circ} \mathrm{C}$ ) } \\
\hline \multirow[b]{2}{*}{ Levels of BPFS (\%) } & \multicolumn{5}{|c|}{ Storage periods (d) } & \multirow[b]{2}{*}{$P$-value } \\
\hline & 0 & 7 & 14 & 21 & 28 & \\
\hline Control & 5.417 & 6.062 & 5.650 & 5.091 & 5.862 & NS \\
\hline 2.5 & 4.265 & 4.755 & 4.056 & 4.492 & 3.956 & NS \\
\hline 5.0 & 5.018 & 5.944 & 5.372 & 4.619 & 3.884 & NS \\
\hline 7.5 & 5.021 & 5.626 & 4.583 & 4.564 & 4.880 & NS \\
\hline 10.0 & 5.127 & 5.499 & 5.191 & 5.490 & 4.283 & NS \\
\hline 12.5 & 5.239 & 5.281 & 4.456 & 4.129 & 4.065 & $0.002^{d}$ \\
\hline$P$-value & NS & NS & NS & NS & NS & - \\
\hline \multirow{7}{*}{\multicolumn{6}{|c|}{$\begin{array}{l}\text { Day } \\
\text { Level } \\
\text { Temperature } \\
\text { Level } \times \text { day } \\
\text { Level } \times \text { temperature } \\
\text { Temperature } \times \text { day } \\
\text { Level } \times \text { temperature } \times \text { day }\end{array}$}} & $<0.0001$ \\
\hline & & & & & & $<0.0001$ \\
\hline & & & & & & $<0.0001$ \\
\hline & & & & & & $<0.0001$ \\
\hline & & & & & & $<0.0001$ \\
\hline & & & & & & $<0.0001$ \\
\hline & & & & & & $<0.0001$ \\
\hline
\end{tabular}

Note: NS, nonsignificant.

${ }^{a} y=8.291-2.8309 x+0.4214 x^{2}, R^{2}=0.75$.

${ }^{b} y=8.6533-2.548 x+0.3461 x^{2}, R^{2}=0.82$.

$c^{c} y=4.2924+1.3131 x-0.2005 x^{2}, R^{2}=0.81$.

${ }^{d} y=5.514-0.2771 x, R^{2}=0.82$.

the high soluble fiber content present in BPFS, chiefly pectin (18.34\%). These fibers, when present in the diet, can increase the viscosity of the material in the small intestine of the bird and can reduce the digestibility and absorption of nutrients, resulting in higher feed intake (Hetland et al. 2004), in an attempt to meet any possible nutrient deficiency, thereby limiting the feed efficiency for maximum growth (feed conversion).

The egg weight, egg mass, eggshell, eggshell thickness, and Haugh unit did not differ $(P>0.05)$ with increasing levels of the by-product of passion fruit seed (Table 2), justifying its use at a level of $12.5 \%$, mainly to reduce environmental pollution, which can occur if the byproduct does not arrive at the correct destination. Studies with the residue of passion fruit have shown that it does not interfere in the performance and carcass yield of broilers at $42 \mathrm{~d}$ (Togashi et al. 2008). In laying hens, there are no published studies on this by-product in their food, thus making it a new option for the producer. The specific gravity of the eggs showed a linear increase $(P<0.05)$ as the BPFS was included in the diets with the highest obtained with $12.5 \%$ inclusion, which is the only treatment that differed $(P<0.05)$ from the control diet. In diets rich in fiber, it is expected that the shell quality will be poorer, due to the negative effect of fiber on the absorption of calcium (Buzinato et al. 2006). However, this was not observed in the present study.

Total cholesterol and blood triglyceride levels showed a linear decrease effect $(P<0.05)$ with the inclusion of BPFS in the diet (Table 2). This result was expected due to the presence of pectin in BPFS (18.34\%), which, when available in large quantities, may reduce total cholesterol and LDL cholesterol in the blood (Ramos et al. 2007). On the other hand, Togashi et al. (2008) observed no effect $(P>0.05)$ with the use of passion fruit by-products (peel and seed) on blood 
cholesterol levels in broilers at $42 \mathrm{~d}$ of age. Chau and Huang (2005) reported that hamsters fed fiber obtained from passion fruit seed (P. edulis) had reduced serum triglyceride levels, thus demonstrating that the use of insoluble fiber obtained from passion fruit seed could influence serum triglyceride levels in rodents.

There was interaction $(P<0.05)$ among the levels of inclusion of BPFS, time (days), and storage environment (Table 3). In the nonrefrigerated environment, there was an effect $(P<0.05)$ on yolk oxidation after $14 \mathrm{~d}$ of storage, extending to the 28th d; the best level of BPFS was 3.36 and 3.69 after 14 and $21 \mathrm{~d}$ of storage, respectively. The highest level of BPFS (12.5\%) showed has a lower oxidation value (28th d), indicating higher antioxidant power in the nonrefrigerated environment. The TBARS values in eggs in the final storage period are directly related to the lipid composition and the transfer of the antioxidant used in the feed of the birds providing the eggs (Shahryar et al. 2010). BPFS is characterized by a high content of fatty acids, including linoleic acid (63.98\%), oleic acid (19.53\%), palmitic acid (11.29\%), stearic acid (3.54\%), and linolenic acid $(0.40 \%)$. The good oxidative stability observed in this study can be attributed to vegetable oils possessing potent antioxidants such as isoflavones, tocopherols, and polyphenols (Vernaza et al. 2012), which are present in high amounts in BPFS (Zeraik et al. 2010). The BPFS used presents $4.01 \mathrm{mg} \mathrm{GAE}^{-1}$ of phenolic compounds. LópezVargas et al. (2013), using the pulp and seed of the passion fruit, found similar value of $4.31 \mathrm{mg} \mathrm{GAE}^{-1}$.

In the refrigerated environment, the $12.5 \%$ inclusion level of BPFS linearly decreased $(P<0.05)$ lipid oxidation in the yolk up to $28 \mathrm{~d}$ of storage, demonstrating possible antioxidant potential. Keeping eggs refrigerated prolongs shelf life and reduces the degradation of its internal components (Lopes et al. 2012).

Lopes et al. (2010) showed that oils such as passion fruit seed, which have a high content of polyunsaturated fatty acids, can be successfully employed in the food industry, for example, in the production of margarines which are consumed without heat treatment, and are therefore less susceptible to oxidation.

\section{Conclusion}

The by-product of passion fruit seed can be included in the diet of laying hens at a level up to $5.0 \%$ without compromising bird performance and $\mathbf{1 2 . 5 \%}$ for egg quality, and this level reduced yolk lipid oxidation and increased the shelf life of the eggs. The BPFS seed has been shown to be a new ingredient option, especially in regions with considerable fruit production. These by-products present excellent potential for the use in animal feed and can thus minimize the environmental impact of juice production.

\section{Acknowledgements}

We thank the State University of Maringa (UEM), the Coordination for the Improvement of Higher Education
Personnel (CAPES) and Fruteza - Natural Juices Ltda, which enabled the development of this work.

\section{References}

Buzinato, E.F., Almeida, R.N.A., and Mazeto, G.M.F.S. 2006. Biodisponibilidade de Cálcio Dietético. Arq. Bras. Endocrinol. Metab. 50: 852-861. doi:10.1590/S000427302006000500005.

Chau, C.F., and Huang, Y.L. 2005. Effects of the insoluble fiber derived from Passiflora edulis seed on plasma and hepatic lipids and fecal output. Mol. Nutr. Food Res. 49: 786-790. doi:10.1002/(ISSN)1613-4133.

Claro, R.M., and Monteiro, C.A. 2010. Renda familiar, preço de alimentos e aquisição domiciliar de frutas e hortaliças no Brasil. Rev. Saúde Públ. 44: 1014-1020. doi:10.1590/ S0034-89102010000600005. PMID:27355465.

Franco, L.L. 1996. As sensacionais 50 plantas medicinais campeãs de poder curativo. Editora Santa Mônica, Curitiba, Brazil.

Haugh, R.R. 1937. The Haugh unit for measuring egg quality. U.S. Egg Poult. Mag. 4: 552.

Hetland, H., Choct, M., and Svihus, B. 2004. Role of insoluble non-starch polysaccharides in poultry nutrition. World Poultry Sci. J. 60: 415-422. doi:10.1079/WPS200325.

Hy-Line International. 2009-2011. Hy-line variety W-36 commercial management guide 2009-2011. Hy-Line International, West Des Moines, IA. 22 p.

IBGE. 2013. Instituto Brasileiro de Geografia e Estatística anuário estatístico do Brasil: Aspecto das atividades agropecuárias e extração vegetal. IBGE, Rio de Janeiro, Brazil. 172 p.

Jung, S., Jo, C., Kang, M., Ahn, D.U., and Nam, K.C. 2012. Elucidation of antioxidant activity of phosvitin extracted from egg yolk using ground meat. Korean J. Food Sci. An. 32: 162-167. doi:10.5851/kosfa.2012.32.2.162.

Kobori, C.N., and Jorge, N. 2005. Caracterização dos óleos de algumas sementes de frutas como aproveitamento de resíduos agroindustriais. Ciênc. Agrotec. 29: 1008-1014. doi:10.1590/S1413-70542005000500014. PMID:27356284.

Leonel, S., Leonel, M., and Duarte-Filho, J. 2000. Principais produtos e subprodutos obtidos do maracujazeiro. Informe Agropecuário, 21: 86-88.

Lopes, L.L.R.A., Silva, Y.L., Nunes, R.V., Takahashi, S.E., and Mori, C. 2012. Influência do tempo e das condições de armazenamento na qualidade dos ovos comerciais. Rev. Cient. Elet. Med. Vet. 18: 1-15.

Lopes, R.M., Sevilha, A.C., Faleiro, F.G., Silva, D.B., Vieira, R.F., and Agostini-Costa, T.S. 2010. Estudo comparativo do perfil de ácidos graxos em semente de passifloras nativas do cerrado brasileiro. Rev. Bras. Frutic. 32: 498-506. doi:10.1590/ S0100-29452010005000065.

López-Vargas, J.H., Fernández-López, J., Pérez-Álvarez, J.A., and Viuda-Martos, M. 2013. Chemical, physico-chemical, technological, antibacterial and antioxidant properties of dietary fiber poder obtained from yellow passion fruit (Passiflora edulis var. flavicarpa) co-products. Food Res. Int. 51: 756-763. doi:10.1016/j.foodres.2013.01.055.

Macoris, M.S., Janzantti, N.S., Garruti, D.S., and Monteiro, M. 2011. Volatile compounds from organic and conventional passion fruit (Passiflora edulis F. Flavicarpa) pulp. Food Sci. Technol. 31: 430-435.

Martin, C.A., Almeida, V.V., Ruiz, M.R., Visentainer, J.E.L., Matshushita, M., Souza, N.E., and Visentainer, J.E. 2006. Ácidos graxos poliinsaturados ômega-3 e ômega-6: importância ocorrência em alimentos. Rev. Nutr. 19: 761-770. doi:10.1590/S1415-52732006000600011. 
Ramos, A.T., Cunha, M.A.L., Sabaa-Srur, A.U., Pires, V.C.F., Cardoso, M.A.A., Diniz, M.F.M., and Medeiros, C.C.M. 2007. Uso de Passiflora edulis $f$. flavicarpa na redução do colesterol. Rev. Bras. Farmacogn. 17: 592-597. doi:10.1590/S0102695X2007000400019.

Rostagno, H.S., Albino, L.F.T., Donzele, J.L., Gomes, P.C., Oliveira, R.F., Lopes, D.C., Ferreira, A.S., and Barreto, S.L.T. 2011. Tabelas brasileiras para aves e suínos: composição de alimentos e exigências nutricionais. 3rd ed. Universidade Federal de Viçosa, Viçosa, MG, Brazil. 119 p.

SAEG. 2007. Statistical analysis system and genetics, version 9.1. Fundação Arthur Bernardes - UFV, Viçosa, Brazil.

Shahryar, H.A., Salamatdoust, R., Azar, S.C., Ahadi, F., and Vahdatpoor, T. 2010. Lipid oxidation in fresh and stored eggs enriched with dietary 3 and 6 polyunsaturated fatty acids and vitamin $\mathrm{E}$ and $\mathrm{A}$ dosages. Afr. J. Biotechnol. 9: 1827-1832.
Silva, D.J., and Queiroz, A.C. 2006. Análises de alimentos: métodos químicos e biológicos. 3rd ed. Universidade Federal de Viçosa - UFV, Viçosa, Brazil. 235 p.

Singleton, V.L., and Rossi, J.A., Jr. 1965. Colorimetry of total phenolics with phosphomolybdic-phosphotungstic acid reagents. Am. J. Enol. Vitic. 16: 144-158.

Togashi, C.K., Fonseca, J.B., Soares, R.T.R.N., Costa, A.P.D., Silveira, K.F., and Detmann, E. 2008. Subprodutos do maracujá em dietas para frangos de corte. Acta Sci. Anim. Sci. 30: 395-400.

Vernaza, M.G., Dia, V.P., de Mejia, E.G., and Chang, Y.K. 2012. Antioxidant and antiinflammatory properties of germinated and hydrolysed Brazilian soybean flours. Food Chem. 134: 2217-2225. doi:10.1016/j.foodchem.2012.04.037.

Zeraik, M.L., Pereira, C.A.M., and Yariwake, J.H. 2010. Maracujá: um alimento funcional? Rev. Bras. Farmacogn. 20: 459-471. doi:10.1590/S0102-695X2010000300026. 